\title{
Harmonization Of Gender Relations And Moral Development
}

\section{${ }^{1}$ Masuda Kamildjanovna Khashimova, ${ }^{2}$ Valijon Gafurjonovich Maxsudov, ${ }^{3}$ Feruz Hasanovich Gaffarov, ${ }^{4}$ Anvar Abdirasulovch Allamuradov, ${ }^{5}$ Yayra Melieva, ${ }^{6}$ Yulduz Turaevna Ismoilova}

\author{
${ }^{1}$ Associate Professor, Tashkent Institute of Engineers of Irrigation and Agricultural Mechanization, Tashkent, \\ Uzbekistan. \\ E-mail: xmk_59@mail.ru. \\ ${ }^{2} \mathrm{PhD}$, Tashkent Medical Academy, Tashkent, Uzbekistan. \\ E-mail: doktorant-2014@mail.ru. \\ ${ }^{3}$ Doctor of Philosophy in Pedagogy (PhD), Institute of Pedagogical Innovations, Management of Vocational \\ Education and Retraining and Advanced Training of Teachers, Tashkent, Uzbekistan. \\ ${ }^{4}$ Teacher, Termez branch of Tashkent State Pedagogical University named after Nizami, Termez, Uzbekistan. \\ ${ }^{5}$ Senior teachers, Institute for retraining and advanced training of directors and specialists of preschool education \\ organizations, Tashkent, Uzbekistan. \\ ${ }^{6}$ Teacher, Karshi State University, Karshi, Uzbekistan
}

Article History: Received:11 January 2021; Accepted: 27 February 2021; Published online: 5 April 2021

\begin{abstract}
The article examines the issues of gendered relations, the improvement of the status of women and social progress, analyzes the issue of the gender division of labor, the gender gap indicator, the gap between women and men, analyzes the current position of women in the family and in society, examines the problems of rational organization and use of female labor with taking into account its morphophysiological and psychological characteristics, creating optimal conditions for a harmonious combination by women professional and family functions, issues of interrelation and mutual influence of professional employment and social status of women.
\end{abstract}

Key concepts: gender, gender policy, gender gaps, global gender gap, gender equality, female emancipation.

\section{Introduction}

There has not been and does not exist a single society in which all its members were equal. Societies without stratification, with real equality of their members, is a myth that has never become a reality in the entire history of mankind. In what forms is social stratification expressed? Take primitive society, for example. Inequality in this society was expressed in the division into groups by gender, age with different privileges and responsibilities of each group, in the presence of a privileged and influential group of tribal leaders, in the presence of the most influential and respected leader, in the existence of outlaws living "outside the law" division of labor both within the tribe and between tribes, in different levels of life. If we cannot find a society without stratification in antiquity, then, all the more, it is useless to try to find it in the later epochs of developed and complex civilizations.

Although it is written in almost all constitutions of modern democratic states that "all people are equal," only a completely naive person can believe that this is indeed the case. As soon as people come together to perform any activity, from teamwork, entertainment to the creation of a state, the organization and differentiation of a social group occurs. Gradations appear spontaneously hierarchies, leaders, social aspirations. Family, church, sect, political party, business organization, gang of robbers, trade union, scientific society, in short, any organized social group stratifies due to its constancy and organization. So, each society is stratified and differs from one another depending on the type of stratification. Differences can even be within the same society, at the same time. But it is possible to single out a universal model of stratification, which is inherent in every society. This is the division of people by sex, i.e. on men and women. Just like clan and class, gender makes a meaningful difference between people and always in favor of men. Can you imagine any society in which women would be at the highest stage of social stratification? Regardless of what system society can use to divide people into different layers, gender is an essential element of such differences within each layer [6]. Social relations between the sexes are not determined only by their biological characteristics. At different stages of historical development and in different social conditions, the roles of men and women were determined in such a peculiar way that it was completely impossible to explain this by physiological differences. In other words, the range of social roles is much wider than physiological differences.

Gender emphasizes that male and female roles in society are socially constructed and defined. Therefore, their change towards a more equitable distribution of resources and income, rights and obligations, etc. does not undermine the foundations of human society, as the defenders of traditional foundations try to convince us, but, on the contrary, are a way to achieve true harmony and ensure human rights. Over the past 
century, and in particular over the past few decades, tremendous progress has been made towards achieving gender equality. Women were at the forefront of the struggle to achieve these results.

Women have overcome many barriers by changing living conditions and contributing to the expansion of social and political change. These movements may have varied from country to country in their content, pace and scope, but they all pursued a common goal - to improve the status of women and social progress. At the first stage, the main task of the women's movement was to obtain legal rights: the right to citizenship, the right to vote, the right to access such social services as education and health care. As a result, women acquired the right to elect and be elected to legislative bodies, the right to dispose of property, the right to property and children in case of divorce, the opportunity to engage in science, social, state, political activities, etc. Obtaining the same legal rights for women as for men did not automatically exclude all types of discrimination against women. Women's movements around the world began to advocate for equal access to economic opportunities. Access to assets and services was considered critical, including land, raw materials, credit, financial and technical services. As women's participation in economic activities increased, there was a need for overcoming obstacles to advancement in economic decision-making and employment of women. But it should be noted that the issue of women's employment is still relevant.

\section{Research materials}

The gender division of labor differs significantly from country to country. Thus, the percentage of women involved in any business other than domestic activities depends on society. This situation is caused by differences in basic cultural values and beliefs (Alesina \& Giuliano, 2010). They tend to be passed from parent to child and remain fairly stable over time. Therefore, gender issues and gender indicators differ in their specificity. Uzbekistan's gender growth rate varies between 0.692 (2005) and 0.708 (2009), where 1 point represents the achievement of absolute equality [9]. The latest score on the GPR scale ranks Uzbekistan 99th out of 155 countries assessed in $2009 \mathrm{~d}$. Similarly, according to the Gender Gap Indicator developed by the World Economic Forum, Uzbekistan has made little progress in closing this gap and received a score of 0.691 in the period 2006-2009. (with a score of 1 representing absolute equality). The Gender Gap Indicator measures the gaps between women and men in access to resources and opportunities, regardless of the level of development of a country, and takes into account four main categories:

-economic participation and opportunities;

- the level of education;

- health and life expectancy;

- the expansion of political rights and opportunities.

In 2012, Uzbekistan was awarded 56th place out of 86 non-OECD countries and received an overall score of 0.304 .9 In this case, a score of " 0 " represents a situation of equality and a score of "1" indicates that women are exposed to discrimination. In Uzbekistan, gender gaps calculated by sub-indices are relevant. Both the Global Gender Gap Indicator and the Gender Equality Indicator (GEF), a methodology developed by Social Watch, point to near-complete gender equality in education (enrollment, education and literacy) and health (sex ratio at birth and healthy life expectancy). Uzbekistan has developed several policy documents related to women's rights at the national level. The government has given legal effect to two national action plans to implement the recommendations of the CEDAW Committee, the first one came into force in 2006 (in response to a review of Uzbekistan's second and third periodic reports), and the second in 2010 (to implement the findings of the CEDAW Committee, made during the fourth periodic review). The 2010 National Action Plan (Annex 1 to Minutes of the Cabinet Meeting No. 10-7) was approved by the Prime Minister and is an international commitment high level. National Action Plan to Implement the Recommendations of the CEDAW Committee (2010) The National Action Plan includes 68 measures to be implemented by various ministries, the Women's Committee of Uzbekistan, local authorities, news agencies and non-governmental organizations. This National Action Plan highlighted such important aspects as gender stereotypes, violence against women, trafficking in human beings and low representation of women in leadership positions.

Time use research shows that women spend three times as much time doing unpaid work as men. Women spend nearly $63 \%$ of this time doing household chores, such as cooking, cleaning, washing, ironing and mending clothes. At the same time, men spend only $11.5 \%$ of their time on such activities. Focus group discussions were held in three regions (Bukhara, Jizzakh, and Samarkand viloyats) as part of an ADB-funded study that provides additional insight into the amount of time women typically spend on unpaid household chores House cleaning - 2 hours a day

- Sending children to school and bringing them back - $1 / 2$ hour a day

- Shopping for food and household items - 2-3 hours a day

- Caring for animals and milking cows - uncertain time Both women and men indicated that they spend 1 to 2 hours a day helping children with housework or teaching them a craft.

Despite the fact that traditional stereotypes about men and women continue to exist in Uzbekistan, this situation does not imply that these cultural norms are immutable. Women's Committee cooperating with the Ministry public education and civil society organizations, organized a number of events to "enhance the role of 
fathers in the practice of raising children." For example, "Fathers Meeting" is being promoted among men as a way to communicate with their children's teachers to discuss aspects of parenting, as well as their roles and responsibilities. Within the framework of the reproductive health project, which included aspects of the development of schools for young families, local groups initiated "Schools for Fathers".

The multiple roles of women are presented in a controversial way, as maternal employment is positioned as normative and inevitable, but is sometimes also portrayed as a choice that women make.

This is consistent with how global social policy positions working mothers; that is, not only the obligation and the right to engage in paid work, but also as primary caregivers who are personally responsible for providing appropriate care for children during their work (Sims-Schouten et al., 2007).

A similar study has also been conducted in Australia (Losoncz \& Bortolotto, 2009). In this study, six groups of women of various professions, income levels and social status were interviewed. The study found that most working mothers successfully managed the balance between work and household responsibilities. Besides

Moreover, women's aspirations to become working mothers were not always related to how well they coped with children and household chores. At the same time, the conflict between work and personal life was associated with long working hours, overload and lack of support from other family members, in particular husbands and relatives. Just under $30 \%$ of mothers experienced high levels of conflict between work and personal life, and there was a strong link between work-life balance and poor physical and mental health and low job and family life satisfaction (Coltrane, 2000).

The problems of the rational organization and use of women's labor, taking into account its morphophysiological and psychological characteristics, the creation of optimal conditions for the harmonious combination of professional and family functions by women, the issues of the relationship and mutual influence of professional employment and the social status of women are detailed in the works of Bestuzhev-Lada I.V., Gruzdev E, Chernova, Zh.V, V.A., Baskakova M.E, Bondarenko L.Yu, Mashkova D, Morozova Z.S., Polenina CB, Voronina, O. A, Andreeva, N.I. [2,8,14, 4,3,11,10,13,5,1]. Speaking about the social role of a modern woman, American sociologist E. Boulding notes that this role is associated more with the "wrong sid

society, and not with its "front" side. Discrimination of women persists in a latent form, which results in stable ideas about what is supposed to be "permissible" for women in society. They are barriers in the consciousness and behavior of people, the cause of inequality in the social positions of men and women.

Today a woman is an employee, employee, business woman, she has a conscientious attitude to work, a sense of responsibility, she achieves serious success in any field, holds leadership positions. A working woman experiences not only moral satisfaction from being a sought-after specialist.

She confidently looks into tomorrow, relying on financial independence, and develops as a person. Scientists call this process emancipation. The category "Emancipation" has acquired synonyms and definitions. This is freedom, relaxedness, courage, confidence. An emancipated woman is a strong-willed, decisive and bright person who lives in step with the times. She builds her own life, is able to be happy and give joy to others.

The emancipation of women is an undoubted advantage and development in new areas, as well as a great contribution to the development of society. But, on this are the gifts

women's movements don't end there. Additional responsibilities came, and no one took off the housekeeping and raising children from women. As a result, the weaker sex was overgrown with additional troubles. Since, in the traditional sense, a woman is the keeper of the family hearth. She runs the house, brings up children, and her husband takes care of the material well-being of the family. A woman is a mother and wife who creates coziness in the family, maintains order and cleanliness in the house, a kind atmosphere and warmth of human relations, and also brings up, loves and protects her child, does everything to make him happy. It should be noted in modern society, these functions of a woman remain on her fragile shoulders [15].

It is very difficult to cope alone and with professional duties and household tasks. If there is no help from the outside: a nanny, housekeeper or grandmother, as well as from the state, then the woman finds herself in an impasse. The standard outcome of the situation is early aging due to constant stress, exhaustion or breakdown of marriage and single-parent families, as well as children who do not receive attention. All these problems are becoming more and more urgent in modern society.

In the wake of emancipation in family life, the substitution of concepts occurred in the relationship between a man and a woman.

Foreign researchers warn that gender neutralization is coming, sociologists are sure that the era of biarchy is coming, which means complete equality. A woman, adopting habits, deeds and lifestyle from the stronger sex, departs from femininity and becomes masculine. This image is promoted by literature and films, where decisive, confident girls who do not seek support in the face of men are praised. Such changes also affected family life, emancipation left its mark. Today women give birth to one or two children, and a year later they go to work.

It turns out that instead of creating a family hearth, the woman went to discover new territories. And she devotes most of her energy to work, social work as much as a man. But, the biological potential, bioenergy 
of a woman is not without limit, you have to decide how to distribute it rationally. And now the woman is torn in two directions. When choosing one of them, life becomes boring and incomplete, working in two directions develops, forms new qualities, but overtires and exhausts.

Career growth makes a woman confident, increases self-esteem, leads to material wealth and raises the mother's status to a new level. But in this case, it turns out that male duties are completely performed by the weaker sex. A tired woman in the end may come to a decision that she does not need a family and a husband if she is engaged in providing for the family and raising children alone. Statistics show that modern girls refuse to marry or get divorced when they do not feel help from the stronger sex and the need for a family decreases.

This trend leads to incomplete families and gaps in the upbringing of children. Currently, the problem of combining work and family in the life of a modern woman is being studied both in social psychology and in related fields, in particular, in developmental and educational psychology, family psychology and industrial psychology. In social psychology, this topic is mainly studied in the framework of the role and gender approaches, where such a combination is considered mainly as a conflict. At the same time, from the analysis of the literature, it follows that the this problem from the point of view of the psychology of social cognition, in particular - the theory of social representations. Currently, the most popular model of the family is becoming, where a woman, like a man, puts her career first and only then her family. The second thing worth paying attention to when touching upon the role of women in society is that a woman strives for financial independence. And this need is generated by this stage in the development of society.

\section{Result and discussion}

In our time, women are forced to be active by modern living conditions:

First, in the current conditions, a woman requires further development and self-realization as a person. Because a family is a living organism that either develops or degrades and dies. In order for the family to develop, each of the spouses must develop. As a person develops, every day trying to improve his character traits, learn something new, broaden his horizons and be interesting for other family members, the family becomes strong.

Secondly, in order for a woman to properly raise her children, she needs a good education and an active position, which will allow correctly solving certain problems of the family and children. An educated woman will give her children many times more, and this is very important. Their horizons will expand and it will be much easier for them in life. It will be easier for them to learn, some new knowledge will fall on the existing ones. Neither the kindergarten nor the school give what parents can give. And since the child spends more time with his mother, it is very important that the woman not only feeds, clothe and looks after the children, but also develops.

And for this she herself must be educated. In families where the parents have higher education, the question of whether or not the child goes to college is not even worth it. This is a matter of course, both school and institute. And it will be easier for such children to realize themselves in life.

In a third, it is the active participation of women in the ongoing processes of the renewal of society in the economic, socio-political and spiritual spheres, which is the most important condition for the development of society. You can clearly draw a parallel between: what kind of women, such is society. Because, that women raise their own kind. What she is, such will be the children, and therefore the same society. We must not forget that a woman knows how to give love to her children, man, colleagues, business partners, friends, acquaintances. She can do anything, because she is driven by her mission - to give life. It doesn't matter if it will be a business project, a child or a gourmet meal. But a woman cannot be employed six days a week. She, whatever one may say, will not have time for her family, children, home and herself. And the family will be abandoned in a sense. And her first priority is her own family and above all her own children. Based on this, it is necessary to think about how to create conditions for women's participation in public life. In this respect, it is not logical to equate men and women. It is necessary to take into account the role of women in the family, we believe that such an approach will be democratic.

The democratization of society, which is the core and guarantor of development, is unthinkable without increasing the role of women, without active and specifically female intervention and participation in all our transformation The social status of a woman, focusing in herself diverse social ties and relations, is an indicator of the maturity and well-being of society, a measure of its progressiveness and humanity. The emancipation of women cannot be reversed. Yes, and many ladies will not agree if their achieved rights are taken away from them, albeit with a cart of duties.

It is especially worth noting that today a woman cannot afford to be limited to only one social role, be it a mother or a business woman. The most acceptable combination of a number of status positions, roles both at the level of the institution of the family, relations within the family, and within society as macroinstitute. A modern woman seeks to harmoniously combine and successfully implement those social roles that are important and interesting to her. In modern society, the role of a woman is not only in fulfilling her direct duties at work, but also in realizing herself as a good mother, an exemplary wife and mistress. The main principle for any woman should be the ability to observe the "golden mean" rule [16]. Women have a very honorable and 
important role in society. After all, she, with her heartfelt kindness, must soften conflicts and direct irrepressible male strength and energy in a positive direction.

We will be able to raise the position of women and equalize her importance in building society, then many problems of our society will be solved. But for this it is necessary to create such conditions in society in which a woman will develop calmly both as an exemplary mother and as a qualified specialist. Because as soon as in these conditions the present harmonious development of society is presented.

From all that has been said, we have developed the following recommendatio:

1. The state should purposefully study the possibilities of young mothers and create conditions for their self-realization;

2. It is necessary to pass laws aimed at expanding opportunities for self-realization of women

3. Create conditions for women to master the profession, as well as higher education.

4. To reduce the working day of mothers while maintaining wages, so that in her free time she can be engaged in raising her children.

5. To develop a comprehensive program aimed at supporting and activating women, as it is necessary to strengthen the family and for the development of society, to form a respectful attitude towards women in society.

6. Create such conditions for mothers (economic, psychological, social) in which they can fully develop as a person and educate the young generation properly, at a high level to fulfill their role in society and in the family and at the same time remain healthy.

\section{References}

1. Andreeva, N.I. Formation of gender culture in modern society: philosophical and cultural analysis / NI Andreeva. - Rostov n / a., 2005.

2. Bestuzhev-Lada I.V. In the labyrinths of emancipation: Woman as a social problem / I.V. Bestuzhev Lada, O.V. Zakharova. - M.: Academia, 2000.-201 p.

3. Bondarenko L.Yu. The role of women from the past to the present / L.Yu. Bondarenko // Social Sciences and Modernity - 1996. -№ 6. - P. 163-170.

4. Baskakova M.E. A married woman: family or work? / M.E. Baskakova // Family in Russia. M., 1995. No. 3-4.- S. 101-108.

5. Voronina, O. A. Feminism and gender equality / O. A. Voronina. - M.: Editorial URSS, 2006.

6. Barchunova T.V. Reproduction of gender asymmetry in gender studies / TV Barchunova // Social sciences and modernity. - 2007. - No. 7. - P. 180.

7. Hunger S.I. Family and marriage: historical and sociological analysis / S.I. Hunger. SPb. : Petropolis, 1998.- $271 \mathrm{p}$.

8. Gruzdeva E.B. Combination of professional and family roles by women: problems and ways of solving them / E.B. Gruzdeva // Integration of women into the process of social development. Russian Academy of Management. M.: Education, 2006 .-- 264 p.

9. Women in society: realities, problems, forecasts / N.K. Zakharova, A.I. Posadskaya, N.M. Rimashevskaya; otv. ed. N.M. Rimashevskaya. - M.: Nauka, 1991.-125 p.

10. Moroz V.A., Averkina T.O. Social Roles of Modern Women in Students' Representation // International Journal of Applied and Fundamental Research. - 2016. - No. 11-4. - S. 726-731

11. Mashkova D. about women's emancipation, loneliness and freedom. cosmo.ru/psychology/psychology/plyusy-i-minusy-zhenskoy-svobody/\#part0

12. Morozova Z.S. Evolution of the social status of a woman / Z.S. Morozova // Social and humanitarian knowledge. 2008. - No. 2 - S. 185-194.

13. Polenina C.B. Women's rights in the human rights system: international and national aspects / C.B. Polenina - M.: Institute of State. and Law RAS, 2000.255 p.

14. Stefanov Roman Evgenievich "Scientific aspect №4-2015" - Humanities.

15. The social status of women in society [Electronic resource]. - Access mode:http://knowledge.allbest.ru/sociology/3c0b65635b2bd78b4c 53b89421216c 37_2.html

16. Chernov, J. V. Family policy in Europe and Russia: gender analysis / J. V. Chernov. - SPb. : Norm, 2008.

17. State Committee of the Republic of Uzbekistan on Statistics ( 2013-2019. Gender statistics of Uzbekistan using materials, link to gender.stat.uz

18. Ma'suda K. Khoshimova Problems of Bringing up Moral Perfect Personality. Eastern European Scientific Journal. 2018. 180-184.

19. Masuda Kamildjanovna Khashimova, Durdona Asilovna Mustafoeva, Malokhat Olimovna Kamilova.Integrated approach to moral education. PSYCHOLOGY AND EDUCATION (2021) 28852889. 
20. Rashidovich, B. G., Abdurakhmanovich, A. S., \&Anvarovich, A. A. (2020). Studying the possibility of using mechanical-chemical dispersion for increasing the salt-stability of clay drilling solutions. JournalofCriticalReviews, 7(14), 72-74. doi:10.31838/jcr.07.14.10

21. Fayzullaevich, F. S., Arashovich, M. B., Boboqulovich, T. B., \&Anvarovich, A. A. (2020). Development of technologies for producing catalystfor destructive hydrogenization of asphalt-free oil of heavy sulfur oil. JournalofCriticalReviews, 7(14), 75-80. doi:10.31838/jcr.07.14.11

22. Abdurasulovich, K. J., Yangiboevich, K. M., Anvarovich, A. A., Xolmurodovich, G. A., \&Abdurasulovich, K. O. (2020). Opportunities and results to increase the effectiveness of multimedia teaching in higher education. JournalofCriticalReviews, 7(14), 89-93. doi:10.31838/jcr.07.14.13

23. Muradilloyevich, I. U., Tanzilovch, O. K., Anvarovich, A. A., \&Baxodirovna, S. I. (2020). Improvement of teaching methodology by using modeling programs of engineering education in higher education of uzbekistan. JournalofCriticalReviews, 7(14), 81-88. doi:10.31838/jcr.07.14.12

24. Dustnazar Omonovich Khimmataliev, Kakhramon Tanzilovich Olmov, Ranajon Matyakubovna Abdullaeva, Bobirjon Bakhodirovich Ergashev, Khadicha Toshbaevna Chulponova. Mechanisms of professional competence development in future teachers based on pedagogical and technical knowledge. PSYCHOLOGY AND EDUCATION (2021) 2838-2844.

25. Khimmataliev D., Khakimov J., Daminov O., Rakhmatova F. Criteria and indicators for assessing the level of professional training of future teachers of vocational training at a training module // Journal of critical reviews. ISSN - 2394-5125. Vol 7, Issue 5, 2020 - p. 428-431. doi:10.31838/jcr.07.05.89

26. Ismailova, Z., Khimmataliev, D., Khashimova, M., Fayzullaev, R., \& Sadikova, F. (2019). The role of modern women in society and family. Opcion, 35(Special Issue 21), 734-751

27. Ismailova, Z. K., Khimmataliev, D. O., Khashimova, M. K., Baybaeva, M. K., \& Ergashev, B. B. (2020). Integrative approach to designing the content of secondary specialized vocational education. Opcion, 36(91), 25-41.

28. Ismailova, Z., Choriev, R., Musurmanova, A., \& Aripjanova, M. (2020). Methods of training of teachers of university on advanced training courses. Journal of Critical Reviews. Innovare Academics Sciences Pvt. Ltd. https://doi.org/10.31838/jcr.07.05.85

29. Karabaevna, I. Z., Omonovich, K. D., Abduqunduzovna, B. G., Farmonovna, B. Z., \& Raxmatullaevna, R. L. (2020). Content of development of students educational activity in the context of mobilization of education. Journal of Critical Reviews. Innovare Academics Sciences Pvt. Ltd. https://doi.org/10.31838/jcr.07.05.77

30. Dustnazar Omonovich Khimmataliev, Jamshid Oktyamovich Khakimov, Shakhlo Sadullaevna Sharipova, Muzaffar Farmonovich Turaev, Muzaffar Jumaevich Gofirov, Zulfiya Qayumovna Murodova. Formation of didactic competence of students as a pedagogical problem. PSYCHOLOGY AND EDUCATION (2021)57(1) 5363-5373.

31. Dustnazar Omonovich Khimmataliev, Sayfiddin Shamsiddinovich Bakhriddinov, Zukhra Kosimjonovna Jumananazarova. Case-study method in students training. PSYCHOLOGY AND EDUCATION (2021)57(1) 5374-5379. 